\title{
Behavior of some Eggplant Varieties in the Vidra Area - Ilfov
}

\author{
Mihaela Alina BUZATU ${ }^{*}$, Marcel COSTACHE ${ }^{2}$, Mihaela CROITORU ${ }^{3}$, Stelica CRISTEA ${ }^{4}$ \\ ${ }^{1}$ Engineering and Management of Vegetal and Animal Resources Doctoral School, UASMV Bucharest, \\ 59 Marasti Blvd, District 1, Bucharest, Romania \\ ${ }^{2}$ Research and Development Institute for Vegetable and Flower Growing Vidra, No.22 Calea București \\ Street, Vidra, Ilfov, Romania \\ ${ }^{3}$ Research \& Development Station for Agricultural Plants on Sandy Soils Dabuleni, 130 Victoria Street, \\ Dăbuleni-Dolj, Romania \\ ${ }^{4}$ University of Agronomic Sciences and Veterinary Medicine of Bucharest, 59 Marasti Blvd, District 1, \\ Bucharest, Romania \\ *corresponding author: buzatumihaelaalina@yahoo.com
}

Bulletin UASVM Horticulture 75(1) / 2018

Print ISSN 1843-5262, Electronic ISSN 1843-536X

DOI:10.15835/buasvmcn-hort: 000418

\begin{abstract}
The main purpose of the experiences organized at Research and Development Institute for Vegetable and Flower Growing Vidra was to evaluate the behavior of different cultivars of eggplants in specific soil and climate conditions of the Vidra area and to identify those with high yields, with quality fruits and tolerant to soil borne pathogens attack. In 2016, 12 cultivars of eggplants were studied: 6 non-hybrid varieties (Daniela, Luiza, Dragaica, Zaraza, Belona, Black Beauty) and 6 hybrids (Andra F1, Rebeca F1, Bibo F1, Clorinda F1, Mirabelle F1, Epic F1).The highest yield was achieved in Rebeca F1 and Luiza cultivars. The highest vitamin $\mathrm{C}$ content was realized at Rebeca F1, Luiza, and Zaraza cultivars. The Mirabelle F1 hybrid and Black Beauty variety presented a reduced sensitivity to Verticillium dahliae and Fusarium oxysporum f. sp. melongenae.
\end{abstract}

Keywords: eggplants, fruit quality, yield

\section{Introduction}

Eggplants (Solanum melongena L.), one of the main vegetable species cultivated in Romania, is grown on an area exceeding 8000 hectares, with a total yield of 132 thousand tonnes in 2016 (FAO, 2016). Eggplant fruit, although having a lower nutritional value compared to other vegetable species, are highly appreciated due to taste and content in anthocyanins, carotene, vitamin C, vitamin PP, aspartic acid, malic acid, pectic substances etc. According to data provided by the US Department of Agriculture on the nutrient content of fresh vegetables, eggplants have an energy value of $104 \mathrm{KJ}$ ( $25 \mathrm{Kcal}) / 100 \mathrm{~g}$ of fresh product. Fruits have a low carbohydrate content
(5.88 g), sugar (3.53 g), fiber ( $3 \mathrm{~g})$, fat (0.18 g) and protein $(0.98 \mathrm{~g}$ ) (USDA, 2016). For consumption, there are preferred eggplants varieties which are productive, tolerant to the attack of soil borne pathogens and with high dry matter content. San José et al. (2014) observed that the growing condition plays a major role in determining the composition of eggplant fruit. Environmental and genotypic differences can be exploited to obtain high quality eggplant fruits. According to Bletsos et al. (1999) the yield and quality of eggplant fruit are determined, among others, by cultivation form, organic and mineral fertilization, soil moisture content and pathogen infection rates. 
Table 1. The main characteristics of eggplants cultivars (Vidra, 2016)

\begin{tabular}{|c|c|c|c|c|c|c|}
\hline \multirow{2}{*}{ Variety/hybrid } & \multirow{2}{*}{ Fruit shape } & \multirow{2}{*}{$\begin{array}{c}\text { Average } \\
\text { weight } \\
\text { of fruit (g) }\end{array}$} & \multirow{2}{*}{$\begin{array}{l}\text { Yield } \\
\text { (t/ha) }\end{array}$} & \multirow{2}{*}{$\begin{array}{c}\text { Relative yield } \\
\text { versus average- } \\
(\%)\end{array}$} & \multicolumn{2}{|c|}{ Frequency of attacked plants (\%) } \\
\hline & & & & & $\begin{array}{c}\text { Verticillium } \\
\text { dahliae }\end{array}$ & $\begin{array}{c}\text { Fusarium } \\
\text { oxysporum f. sp. } \\
\text { melongenae }\end{array}$ \\
\hline Daniela & $\begin{array}{c}\text { pear shaped } \\
\text { elongated }\end{array}$ & 380 & 47.0 & 108.6 & 25.0 & 13.3 \\
\hline Luiza & ovoid elongated & 305 & $50.6^{* *}$ & 115.6 & 36.3 & 9.0 \\
\hline Drăgaica & $\begin{array}{l}\text { cylindrical easily } \\
\text { pear shaped }\end{array}$ & 270 & $48.1^{*}$ & 111.2 & 11.7 & 20.0 \\
\hline Zaraza & piriform & 260 & 43.0 & 99.4 & 19.0 & 11.1 \\
\hline Black Beauty & oval elongated & 350 & $33.3^{\circ 00}$ & 76.9 & 14.2 & 12.6 \\
\hline Belona & $\begin{array}{c}\text { pear shaped } \\
\text { elongated }\end{array}$ & 250 & $34.9^{000}$ & 80.6 & 14.0 & 20.3 \\
\hline Andra & ovoid elongated & 265 & 43.6 & 100.8 & 16.9 & 30.5 \\
\hline Clorinda $\mathrm{F}_{1}$ & oval & 500 & 42.7 & 98.7 & 41.5 & 21.5 \\
\hline Rebeca F1 & cylindrical & 560 & $51.0 * * *$ & 147.9 & 46.4 & 17.8 \\
\hline Epic $\mathrm{F}_{1}$ & oval & 370 & 44.0 & 101.7 & 44.6 & 26.9 \\
\hline${\text { Mirabelle } \mathrm{F}_{1}}_{1}$ & oval elongated & 320 & 42.6 & 98.4 & 8.7 & 7.0 \\
\hline Bibo $F_{1}$ & tears & 290 & $38.2^{\circ}$ & 88.32 & 15.8 & 26.9 \\
\hline $\begin{array}{c}\text { Average } \\
\text { experience }\end{array}$ & - & 343.3 & 43.25 & 100.0 & - & - \\
\hline
\end{tabular}

Table 2. Climatic data in the field (Vidra 2016)

\begin{tabular}{cccccccc}
\hline \multirow{2}{*}{ Month } & \multicolumn{3}{c}{ Temperature $\left({ }^{\circ} \mathrm{C}\right)$} & \multicolumn{2}{c}{ Atmospheric humidity (\%) } & $\begin{array}{c}\text { The precipitations } \\
\text { amounth (mm) }\end{array}$ \\
\cline { 2 - 7 } & average & minimum & maximum & average & minimum & maximum & amounc \\
\hline June & 2.9 & 16.1 & 28.4 & 71.3 & 56.8 & 89.5 & 33.5 \\
\hline July & 23.7 & 17.0 & 31.0 & 59.7 & 48.1 & 78.3 & 2.0 \\
\hline August & 23.4 & 17.5 & 30.6 & 60.6 & 49.5 & 77.2 & 110.0 \\
\hline September & 18.9 & 13.1 & 26.3 & 62.8 & 5.9 & 80.2 & 43.5 \\
\hline October & 12.3 & 6.9 & 13.8 & 78.7 & 71.2 & 87.1 & 85.0 \\
\hline
\end{tabular}

\section{Materials and methods}

The main purpose of the experiences organized at Research and Development Institute for Vegetable and Flower Growing Vidra was to evaluate the behavior of cultivars of eggplants in specific soil and climate conditions of the Vidra area. In 2016, 12 cultivars of eggplants were studied: 6 non-hybrid varieties (Daniela, Luiza, Dragaica, Zaraza, Belona, and Black Beauty) and 6 hybrids (Andra F1, Rebeca F1, Bibo F1, Clorinda F1, Mirabelle F1, Epic F1). The experience was places in randomized blocks, in 3 replicates. During the vegetation period observations were made on plant vigor, shape and weight of fruits as well as on the behavior of the varieties to the attack of soil borne pathogens Verticillium dahliae and Fusarium oxysporum f. sp. melongenae. Once the fruit reached commercial maturity the following determination of quality were carried out: total dry matter (gravimetric method), vitamin C (iodometric method), soluble solids content (refractometric method), total carbohydrates (Fehling Soxhlet method) and titratable acidity (titrimetric method). The production data were statistically processed by the analysis of variance (ANOVA), while the level of significance of the production differences was interpreted with Fisher test (Ciulca S, 2002).

\section{Results and discussion}

Regarding the yield, most of the cultivars exceeded $40 \mathrm{t} / \mathrm{ha}$, with the highest yield on Rebeca F1 hybrid (51.0 t/ha) and Luiza variety (50.6 t/ha). Rebeca F1 and Clorinda F1 hybrids were remarked by the fruit weight ( $560 \mathrm{~g}$ and $500 \mathrm{~g}$ respectively). 
Table 3. Biochemical composition of fruits in different cultivars of eggplants (Vidra, 2016)

\begin{tabular}{cccccccc}
\hline No. & Variety/hybrid & $\begin{array}{c}\text { Water } \\
\text { content } \\
(\%)\end{array}$ & $\begin{array}{c}\text { Total dry } \\
\text { matter }(\%)\end{array}$ & $\begin{array}{c}\text { Soluble } \\
\text { dry matter } \\
(\%)\end{array}$ & $\begin{array}{c}\text { Acidity } \\
(\mathrm{g})\end{array}$ & $\begin{array}{c}\text { Carbohydrate } \\
(\%)\end{array}$ & $\begin{array}{c}\text { Vitamin C } \\
(\mathrm{mg})\end{array}$ \\
\hline 1 & Rebeca F1 & 91.01 & 8.99 & 4.7 & 0.32 & 3.90 & 9.68 \\
\hline 2 & Zaraza & 91.59 & 8.41 & 3.5 & 0.30 & 2.96 & 7.47 \\
\hline 3 & Luiza & 92.09 & 7.91 & 3.3 & 041 & 2.74 & 8.80 \\
\hline 4 & Drăgaica & 92.59 & 7.41 & 3.6 & 0.30 & 3.00 & 7.04 \\
\hline 5 & Daniela & 91.90 & 8.10 & 3.3 & 0.32 & 2.70 & 5.28 \\
\hline 6 & Clorinda & 93.84 & 6.16 & 3.1 & 0.23 & 2.60 & 3.52 \\
\hline 7 & Epic F1 & 93,42 & 6.58 & 3.6 & 0.36 & 3.00 & 5.28 \\
\hline 8 & Andra F1 & 90.67 & 9.33 & 4.0 & 0.41 & 3.35 & 3.52 \\
\hline 9 & Mirabelle F1 & 91.18 & 8.82 & 3.7 & 0.39 & 3.07 & 5.28 \\
\hline 10 & Black Beauty & 92.38 & 7.62 & 3.9 & 0.28 & 3.20 & 7.04 \\
\hline 11 & Belona & 91.94 & 8.06 & 3.5 & 0.32 & 2.91 & 3.52 \\
\hline 12 & Bibo F1 & 93.56 & 6.44 & 3.5 & 0.32 & 2.90 & 5.28 \\
\hline \multicolumn{2}{r}{ Media varieties } & $\mathbf{9 2 . 1 8}$ & $\mathbf{7 . 8 2}$ & $\mathbf{3 . 6 4}$ & $\mathbf{0 . 3 3}$ & $\mathbf{3 . 0 3}$ & $\mathbf{5 . 9 8}$ \\
\hline Limits in the literature & $\mathbf{9 0 - 9 3}$ & $\mathbf{7 - 1 0}$ & $\mathbf{5}$ & $\mathbf{0 . 2 3}$ & $\mathbf{0 . 7}-\mathbf{5 . 4}$ & $\mathbf{5}$ \\
\hline
\end{tabular}

The Black Beauty and Belona varieties exhibited the lowest yield with significantly negative differences compared to the average of the experiment. Differences have been observed regarding the behavior of the cultivars studied to pathogens attack. The Verticillium dahliae attack was the lowest in the following genotypes: Mirabelle F1, Belona and Black Beauty, and the highest attack was registered with Rebeca F1, Epic F1 and Luiza. Attack of Fusarium oxysporum f. sp. melongenae was the lowest in Mirabelle F1, Luiza, Zaraza and Black Beauty genotypes and more intense in Andra F1, Bibo F1, Epic F1 and Clorinda F1 (Table 1). Black Beauty variety and the Mirabelle F1 hybrid have been shown a low sensitivity to the attack of soil borne pathogens Verticillium dahliae and Fusarium oxysporum f. sp. melongenae.

In the climatic conditions of 2016 (table 2) in the experimental fields of the Research Institute for Vegetable and Flower crop - Vidra, Ilfov district, eggplants have accumulated a total dry matter content of $6.16 \%$ for the Clorinda F1 cultivar and $9.33 \%$ for the cultivar Andra F1, average of cultivars beeing $7.82 \%$. With a higher content than the average of cultivars, were: Rebeca F1, Zaraza, Daniela, Andra F1, Mirabelle F1, Luiza and Belona. The soluble dry mather substance showed values below the average in the literature, ranging from $3.1 \%$ at Clorinda F1 and $4.7 \%$ at Rebeca F1, with an average cultivares of $3.64 \%$. Fruit acidity was reduced to less than $0.5 \mathrm{~g}$ of malic acid per $100 \mathrm{~g}$ of fresh substance. The amount of fruit carbohydrate was between $2.60 \%$ for the Clorinda F1 cultivar and $3.90 \%$ for the Rebeca F1 cultivar, with an average of $3.03 \%$. The vitamin $\mathrm{C}$ content of eggplants fruits was very variable depending on the cultivar studied. The best results were obtained with the following cultivars: Zaraza (7.47 mg), Luiza (8.80 $\mathrm{mg}$ ) and Rebeca F1 (9.68 mg) with an average crop of $5.98 \mathrm{mg}$, and the average of literature is $5 \mathrm{mg}$ (table 3).

\section{Conclusion}

Fruit weight varied between $250 \mathrm{~g}$ (Belona) and $560 \mathrm{~g}$ (Rebeca F1), depending on the cultivar. The yield ranged from $33.3 \mathrm{t} / \mathrm{ha}$ (Zaraza) and $51 \mathrm{t} /$ ha (Rebeca F1). The Luiza variety also had a high yield ( $50.6 \mathrm{t} / \mathrm{ha}$ ). As for the quality of the fruits, in the year 2016, the best results were obtained in the hybrid Rebeca F1 and Luiza variety. The Mirabelle F1 hybrid and the Black Beauty variety were less sensible to the attack of soil borne pathogens Verticillium dahliae and Fusarium oxysporum f. sp. melongenae.

\section{References}

1. Bletsos F. A ., Thanassoulopoulos C .C ., Roupakias D.G. , 1999. Water stress and verticillium wilt severity on eggplant (Solanum melongena L.). J. Phytopathol.147 (4): 243-248.

2. Ciulca S (2002). Tehnică experimentală. Editura Mirton. Timișoara. 
3. Food and Agriculture Organization of the United Nation. Food and agricultural data (2016). http://www.fao. org/faostat/en/\#data/QC. Accessed 13.08.16;

4. San José, R., Sánchez-Mata, M.-C., Cámara, M. and Prohens, J. (2014), Eggplant fruit composition as affected by the cultivation environment and genetic constitution. J. Sci. Food Agric., 94: 2774-2784. doi:10.1002/jsfa.6623

5. United States Department of Agriculture. USDA Food Composition Data bases (2016). https://ndb.nal.usda. gov/ndb/foods/show /2962? manu=\&fgcd=\&ds. Accessed 15.07.16. 